\title{
Role of Interleukin-6 and Oxidative Stress in Mentally Retarded patients
}

\author{
A.F. Abdel Aziz , Faeza A. El-Dahtory ${ }^{b}$, Nivin A. Salah ${ }^{a}$, \\ Bossy M. El-Sallab ${ }^{c^{*}}$ \\ ${ }^{a}$ Biochemistry Division, Chemistry Department, Faculty of Science, ${ }^{\mathbf{b}}$ \\ Genetics Unit, Children Hospital, ${ }^{\mathbf{c}}$ Micro analytical Unit, \\ Faculty of Science, Mansoura University
}

\begin{abstract}
Background: Abnormalities in thyroid state may result in mental retardation. Oxidative stress and elevated serum inerleukin-6 (IL-6) levels have been identified as an important contributor to neurodegeneration. The aim: This work has been carried out to evaluate the interleukin-6, thyroid hormones as well as some parameters related to oxidative stress in mentally retarded patients with chromosomal abnormalities. Methods: karyotyping for blood, serum thyroid stimulating hormone (TSH), free thyroxin (FT4), superoxide dismutase (SOD), catalase(CAT), malondialdehyde (MDA) and interleukin-6 (IL-6) were measured in 60 mentally retarded patients and 30 healthy volunteers included as control groups. Results: Chromosomal abnormalities were studied in 60 mentally retarded patients, 50 of them were Down's syndromes and the other 10 consisted of (translocations, trisomies, ring chromosome, Edward's, Patau and Klinefelter syndromes). Thirty three subjects were euthyroid and 27 subjects were hypothyroid. In euthyroid group there was no significant difference in the values of TSH, FT4 and SOD whereas the values of MDA and CAT were significantly higher compared with control. On the other hand, IL-6 levels were highly significantly increased compared with the control group. In hypothyroid group there was a highly significant increase in TSH and IL-6 levels and a highly significant decrease in SOD, CAT, MDA and FT4 levels compared with those of the control group. Conclusion: Increased oxidative stress and IL-6 as well as hypothyroidism are common in mentally retarded individuals with chromosomal abnormalities. These findings are useful in supporting future antioxidant therapies and chemical inhibitors against the function of IL-6 to improve those patients.
\end{abstract}

Keywords: Chromosomal abnormalities, Interleukin-6, Mentally retarded patients, Oxidative Stress, Thyroid hormones.

\section{INTRODUCTION}

Mental retardation (MR) is a particular state of functioning which begins in childhood and is characterized by decreased intelligence and adaptive skills and also is the most common developmental disorder ${ }^{(\mathbf{1})}$. Down syndrome is the commonest known cause of mild and severe intellectual disability, fetal alcohol syndrome is the $2^{\text {nd }}$ commonest known cause in many countries, endemic cretinism 
caused by iodine deficiency is a common global cause of severe intellectual disability and the prevention of cretinism with iodine is technically simple and cheap ${ }^{(2)}$.

Chromosomal aberrations are disruptions in the normal chromosomal content of a cell and are a major cause of genetic conditions in humans, such as Down syndrome. Chromosomal disorders are the most numerically frequent cause of mental retardation ${ }^{(3)}$.

Thyrotropin releasing hormone (TRH), secreted by the hypothalamus, stimulates the release of thyroid stimulating hormone (TSH) produced by the anterior pituitary gland which, in turn, causes the release of thyroxine $\left(\mathrm{T}_{4}\right)$ and triiodothyronine $\left(\mathrm{T}_{3}\right)$ hormones by the thyroid gland (4). Hypothyroid patients demonstrate deficits in cognitive abilities such as attention, visual perception, memory, language, executive functions as well as depression ${ }^{(5)}$. Abnormalities in thyroid state may affect development and function of the brain and result in mental retardation (MR) ${ }^{(6)}$.

Interleukin 6 (IL-6) is a key proinflammatory cytokine produced by many different cells, including leukocytes, adipocytes, endothelial cells, fibroblasts and myocytes. IL-6 regulates production of adhesion molecules and induces secretion of monocyte chemotactic protein, an important mediator of release of other cytokines, such as tumor necrosis factor- $\alpha$ (TNF- $\alpha$ ) and interleukin- $1 \beta$ (IL-1 $\beta$ ) that subsequently amplify the inflammatory reaction ${ }^{(7)}$. Elevated serum IL-6 levels have been reported in children with Down syndrome $(\mathrm{DS})^{(\mathbf{8})}$. It was found that evidence for selective effects of IL-6 signalling particularly trans-signalling in the developing brain ${ }^{(9)}$.

The production of reactive oxygen species (ROS) in oxygen utilizing organisms is balanced with the production of reducing equivalents and the removal of ROS by antioxidant defense systems in cells and their surrounding microenvironment. Oxidative stress occurs by decreasing in antioxidant defense systems or increasing of ROS or both ${ }^{(\mathbf{1 0})}$. Oxidative stress has been identified as an important contributor to neurodegeneration associated with acute central nervous system (CNS) injuries and diseases ${ }^{(11)}$. Oxidative stress affecting the thyroxin biosynthesis might and this explain the proneness of patients with Down's syndrome (DS) (trisomy 21) to develop hypothyroidism ${ }^{(\mathbf{1 2})}$.

This work has been carried out to evaluate the IL6, thyroid function tests (TSH, FT4) as well as some parameters related to oxidative stress (SOD, CAT activities and MDA levels) in mentally retarded patients with chromosomal abnormalities.

\section{SUBJECTS \& METHODS}

The present study included 60 mental retardation patients who suffer from chromosomal abnormalities. Subjects were collected from Children Mansoura University Hospital, Egypt. The studied cases of mental retardation were with age range (0.0823 years and mean age 9.48 \pm 8.19 years. The control group included 30 healthy cases with age range 0.33-23 years and mean age 9.50 \pm 8.23 years.There was non-significant 
difference between mean age of mentally retarded patients and mean age of control $(\mathrm{P}>0.05)$.

Informed consent was obtained from patients' parents and controls. The research was approved by The Ethical Board of Children Mansoura University Hospital, Egypt.

Six $\mathrm{ml}$ of peripheral blood samples were obtained from each patient and control subject. Samples were divided into two parts. Two $\mathrm{ml}$ of blood were taken in a sterile heparinized syringe used for karyotyping and $4 \mathrm{ml}$ was centrifuged without anticoagulant to separate serum for determination of superoxide dismutase (SOD), catalase (CAT), malondialdehyde (MDA), interleukin6 (IL-6), thyroid stimulating hormone (TSH) and free thyroxine (free $\mathrm{T}_{4}$ ).

Chromosomal analysis was carried by Gimsa stain and the applied imaging computer was used to get the karyotype according to the method of Rooney and Czepulkowski ${ }^{(13)}$.

Serum SOD was measured by commercial kit supplied by Biodiagnostic, Egypt and its principal relies on the ability of the enzyme to inhibit the phenazine methosulphatemediated reduction of nitroblue tetrazolium dye .The increase in absorbance was measured at $560 \mathrm{~nm}$ for $5 \mathrm{~min}$ for control $\left(\triangle \mathrm{A}_{\text {control }}\right)$ and for sample $\left(\Delta \mathrm{A}_{\text {sample }}\right)$ at $25^{\circ} \mathrm{C}$ and results expressed as Percent of inhibition (14). Serum CAT was measured by commercial kit supplied by Biodiagnostic and its principal relies on forming a chromophore with color intensity inversely proportional to the amount of catalase in the original sample. The color measured at $510 \mathrm{~nm}^{(\mathbf{1 5})}$. Serum MDA was measured by commercial kit supplied by Biodiagnostic, Egypt and its principal depends on the absorbance of the resultant pink product measured at $534 \mathrm{~nm}^{(\mathbf{1 6})}$. Serum IL-6 was measured by Boster's human IL-6 ELISA Kit (USA) and it was based on standard sandwich enzyme-linked immune-sorbent assay technology. The O.D. absorbance was measured at $450 \mathrm{~nm}$ in a microplate reader ${ }^{(17)}$. Serum TSH was measured by human thyroid stimulating hormone (TSH) MICRO-ELISA Test Kit (USA) and the assay system utilizes two antibodies (mouse monoclonal) directed against distinct antigenic determinants on the TSH molecule. Specifically, plastic wells are coated with anti-TSH (mouse monoclonal). The concentration of TSH in the patient sample is interpolated from a standard curve relating the absorbance, measured at $450 \mathrm{~nm}$, of each calibrator to the concentration of TSH ${ }^{(\mathbf{1 8})}$. Serum free $\mathrm{T}_{4}$ was measured by enzyme immunoassay kit for the quantitative determination of Free $\mathrm{T}_{4}$ concentration in serum (USA) through competitive enzyme immunoassay analog method for free $\mathrm{T}_{4}{ }^{(19)}$.

\section{STATISTICAL ANALYSIS:}

All statistical analyses were done by a statistical software package "SPSS version 15.0 for Microsoft windows, (SPSS Inc.), with the results expressed as mean \pm standard deviation (Mean \pm SD). The Student unpaired " $t$ " test and the ANOVA test were used for the group comparisons. Significant differences were considered with a $P<0.05$. 


\section{RESULTS}

Through karyotyping we found that 50 mentally retarded patients were Down syndrome and the other 10 mentally retarded patients consisted of two cases that had different translocations $(46 x x, t(5,12)(\mathrm{p} 15 ; \mathrm{q} 12)$ and 46xy t(13;13)), two cases were Edward's syndrome (trisomy 18), one case was Patau syndrome (trisomy 13), three cases had different trisomies (47xy,b4q2.22, $47 x y+8 \quad$ and 47xx,braR11), one case had ring chromosome 46,xy,r(9) and one case was Klinefelter and Down syndrome $(48 x x y+21)$.We classified mentally retarded patients according to thyroid hormones into two groups (Euthyroid and hypothyroid groups). In our study, mentally retarded patients with normal karyotyping were excluded.
As shown in table 1 euthyroid group represented here by thirty-three patients $(55 \%)$ had both serum-free $\mathrm{T}_{4}$ and TSH concentrations within the normal range. Also, there was no statistically significant difference in the values of $\mathrm{TSH}, \mathrm{FT}_{4}$ concentrations and SOD activity $(2.38 \pm 1.21 \mu \mathrm{lU} / \mathrm{ml}$, $\mathrm{P}>0.05 ; 1.37 \pm 0.26 \mathrm{ng} / \mathrm{dl}, \mathrm{P}>0.05$ and $94.99 \pm 0.47 \%, \quad \mathrm{P}>0.05$, respectively) compared with the corresponding values of the control group $(1.95 \pm 0.88 \mu \mathrm{lU} / \mathrm{ml}, \quad 1.41 \pm 0.25 \mathrm{ng} / \mathrm{dl}$ and $95.14 \pm 1.13 \%$, respectively). Whereas the values of CAT activity and MDA concentration were significantly higher $(847.23 \pm 92.05$ U/L, $\quad \mathrm{P}<0.05$ and $\quad 41.01 \pm 13.11$ $\mathrm{nmol} / \mathrm{ml}, \quad \mathrm{P}<0.05, \quad$ respectively) compared with those of control $(802.04 \pm 45.37 \mathrm{U} / \mathrm{L}$ and $33.65 \pm 13.5$ $\mathrm{nmol} / \mathrm{ml}$, respectively) and those of IL-6 were highly significantly higher $(275.48 \pm 126.17 \quad \mathrm{pg} / \mathrm{ml}, \quad \mathrm{P}<0.001)$ compared with the control group $(55.59 \pm 26.37 \mathrm{pg} / \mathrm{ml})$. 
Table 1: Comparison between thyroid stimulating hormone (TSH), free thyroxine $\left(\mathrm{FT}_{4}\right)$, superoxide dismutase (SOD), catalase (CAT), malondialdehyde (MDA) and interleukin-6 (IL-6) in euthyroid mentally retarded patients and control subjects.

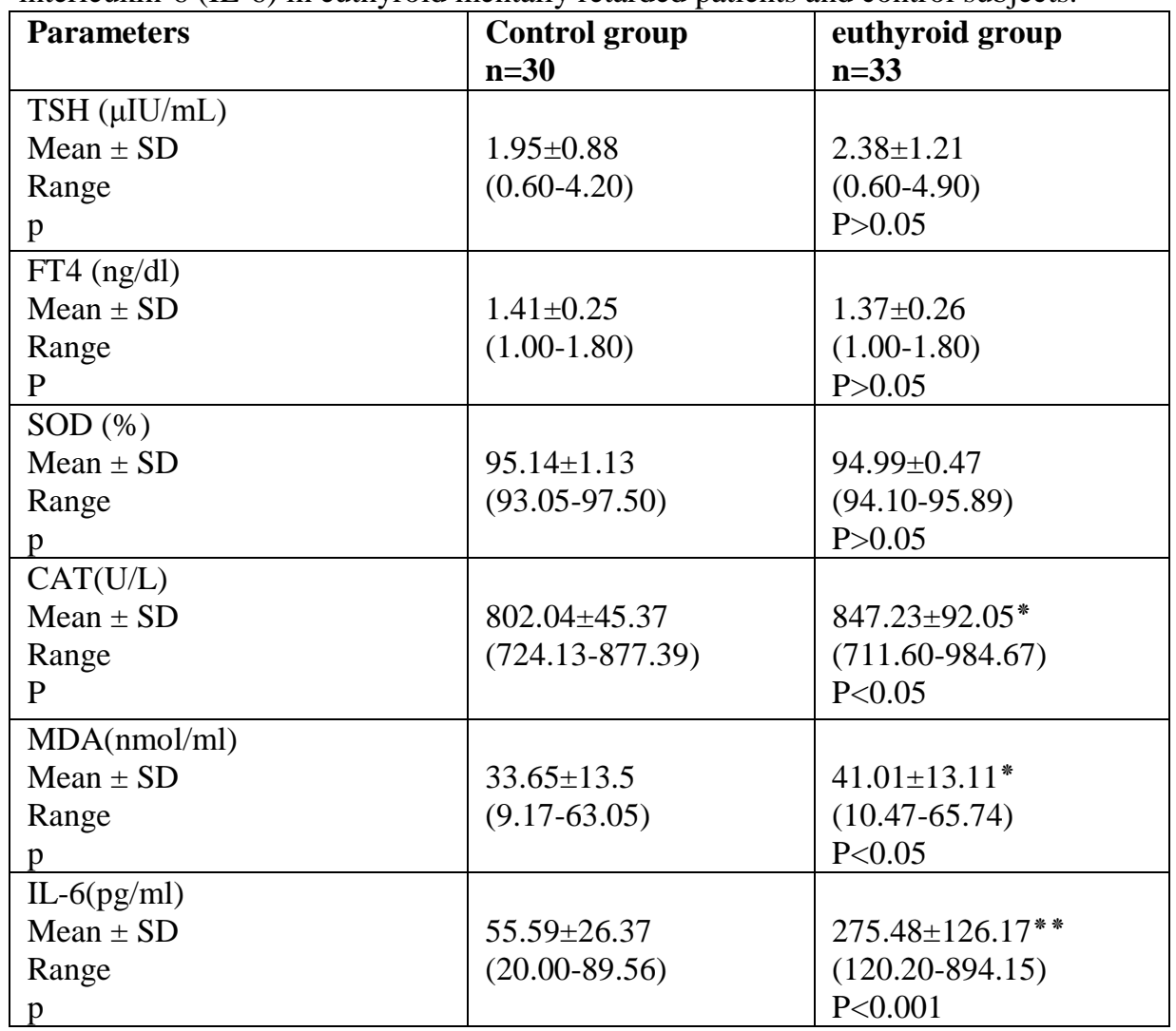

${ }^{*} \mathrm{P}<0.05$ : Significant difference compared to control group.

*** $\mathrm{P}<0.001$ : Highly significant difference compared to control group.

As shown in table 2 the hypothyroid group consisted of 27 patients and exhibited abnormal serum-free $\mathrm{T}_{4}$ and TSH values. There was a highly significant increase in TSH and IL- 6 concentrations (7.7 $\pm 3.16 \mu \mathrm{lU} / \mathrm{ml}, \quad \mathrm{P}<0.001$; $229.82 \pm 45.68 \quad \mathrm{pg} / \mathrm{ml}, \quad \mathrm{P}<0.001$, respectively) compared with those of the control group $(1.95 \pm 0.88 \mu \mathrm{lU} / \mathrm{ml}$; $55.59 \pm 26.37 \mathrm{pg} / \mathrm{ml}$, respectively) and a highly significant decrease in $\mathrm{FT}_{4}$, SOD, CAT and MDA values $(0.71 \pm 0.24 \quad \mathrm{ng} / \mathrm{dl}, \quad \mathrm{P}<0.001$; 92.22 $\pm 0.5 \%, \mathrm{P}<0.001 ; 445.71 \pm 147.57$ $\mathrm{U} / \mathrm{L}, \quad \mathrm{P}<0.001$ and $\quad 20.61 \pm 7.37$ $\mathrm{nmol} / \mathrm{ml}, \quad \mathrm{P}<0.001, \quad$ respectively) compared with those of the control group $(1.41 \pm 0.25 \quad \mathrm{ng} / \mathrm{dl}$; $95.14 \pm 1.13 \% ; 802.04 \pm 45.37 \mathrm{U} / \mathrm{L}$ and $33.65 \pm 13.5 \mathrm{nmol} / \mathrm{ml}$, respectively). 
Table 2: Comparison between thyroid stimulating hormone (TSH), free thyroxine $\left(\mathrm{FT}_{4}\right)$, superoxide dismutase (SOD), catalase (CAT), malondialdehyde (MDA) and interleukin-6 (IL-6) in hypothyroid mentally retarded patients and control subjects.

\begin{tabular}{|c|c|c|}
\hline Parameters & $\begin{array}{l}\text { Control group } \\
\mathbf{n}=30\end{array}$ & $\begin{array}{l}\text { hypothyroid group } \\
\mathbf{n}=27\end{array}$ \\
\hline $\begin{array}{l}\text { TSH }(\mu \mathrm{IU} / \mathrm{ml}) \\
\text { Mean } \pm \text { SD } \\
\text { Range } \\
\text { p }\end{array}$ & $\begin{array}{l}1.95 \pm 0.88 \\
(0.60-4.20)\end{array}$ & $\begin{array}{l}7.7 \pm 3.16^{* *} \\
(1.10-17.70) \\
P<0.001\end{array}$ \\
\hline $\begin{array}{l}\mathrm{FT}_{4}(\mathrm{ng} / \mathrm{dl}) \\
\text { Mean } \pm \mathrm{SD} \\
\text { Range } \\
\mathrm{P}\end{array}$ & $\begin{array}{l}1.41 \pm 0.25 \\
(1.00-1.80)\end{array}$ & $\begin{array}{l}0.71 \pm 0.24^{* *} \\
(0.40-1.60) \\
P<0.001 \\
\end{array}$ \\
\hline $\begin{array}{l}\text { SOD }(\%) \\
\text { Mean } \pm \text { SD } \\
\text { Range } \\
\text { p }\end{array}$ & $\begin{array}{l}95.14 \pm 1.13 \\
(93.05-97.50)\end{array}$ & $\begin{array}{l}92.22 \pm 0.5^{* * *} \\
(91.10-93.05) \\
\mathrm{P}<0.001\end{array}$ \\
\hline $\begin{array}{l}\text { CAT(U/L) } \\
\text { Mean } \pm \text { SD } \\
\text { Range } \\
\mathrm{P}\end{array}$ & $\begin{array}{l}802.04 \pm 45.37 \\
(724.13-877.39)\end{array}$ & $\begin{array}{l}445.71 \pm 147.57^{* *} \\
(91.95-819.05) \\
\mathrm{P}<0.001\end{array}$ \\
\hline $\begin{array}{l}\mathrm{MDA}(\mathrm{nmol} / \mathrm{ml}) \\
\text { Mean } \pm \mathrm{SD} \\
\text { Range } \\
\mathrm{p}\end{array}$ & $\begin{array}{l}33.65 \pm 13.5 \\
(9.17-63.05)\end{array}$ & $\begin{array}{l}20.61 \pm 7.37 * * \\
(7.53-41.11) \\
P<0.001\end{array}$ \\
\hline $\begin{array}{l}\text { IL-6 }(\mathrm{pg} / \mathrm{ml}) \\
\text { Mean } \pm \text { SD } \\
\text { Range } \\
\mathrm{p}\end{array}$ & $\begin{array}{l}55.59 \pm 26.37 \\
(20.00-89.56)\end{array}$ & $\begin{array}{l}229.82 \pm 45.68 * * \\
(150.78-293.25) \\
P<0.001\end{array}$ \\
\hline
\end{tabular}

${ }^{*} \mathrm{P}<0.05$ : Significant difference compared to control group.

" $\mathrm{P}<0.001$ : Highly significant difference compared to control group.

As shown in figure 1 there is a highly significant negative correlation between $\mathrm{TSH}$ and $\mathrm{FT}_{4}(\mathrm{r}=-0.818, \mathrm{p}<0.001)$ in mentally retarded patients. 


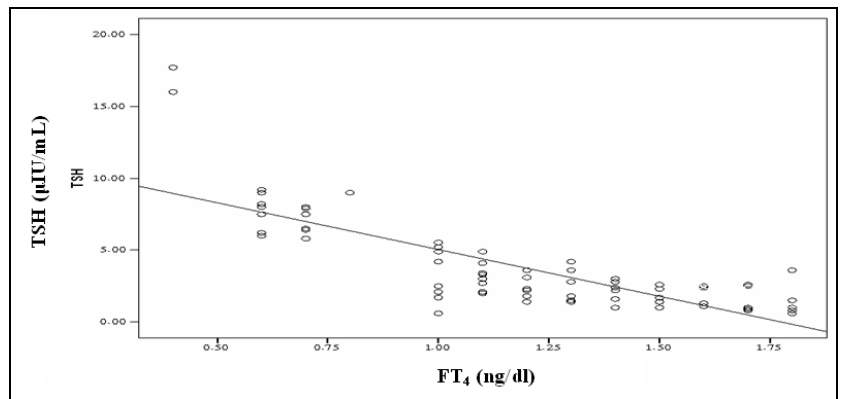

Figure 1: Correlations between thyroid stimulating hormone (TSH) and free thyroxine (FT4) in mentally retarded patients $(r=-0.818, \mathrm{p}<0.001)$.

As shown in figure 2 there is a highly significant negative correlation between SOD and TSH $(r=-0.682, \mathrm{p}<0.001)$ in mentally retarded patients.

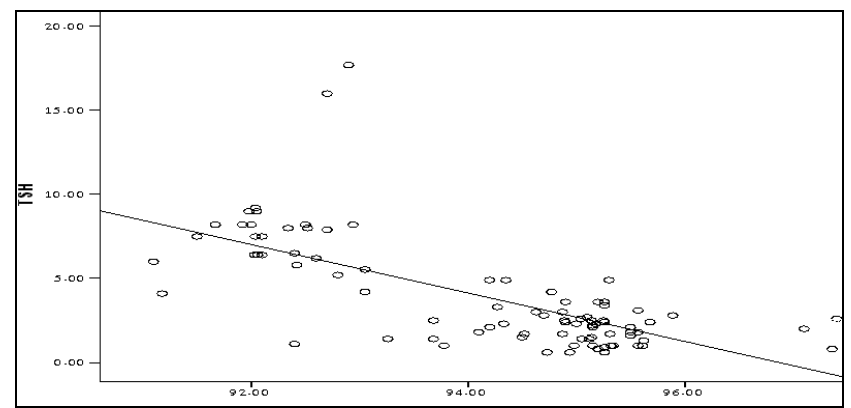

Figure 2: Correlation between thyroid stimulating hormone (TSH) and superoxide dismutase (SOD) in mentally retarded patient $(\mathrm{r}=-0.682, \mathrm{p}<0.001)$.

Figure 3: shows that there is a highly significant negative correlation between TSH and CAT ( $\mathrm{r}=-0.718, \mathrm{p}<0.001)$.

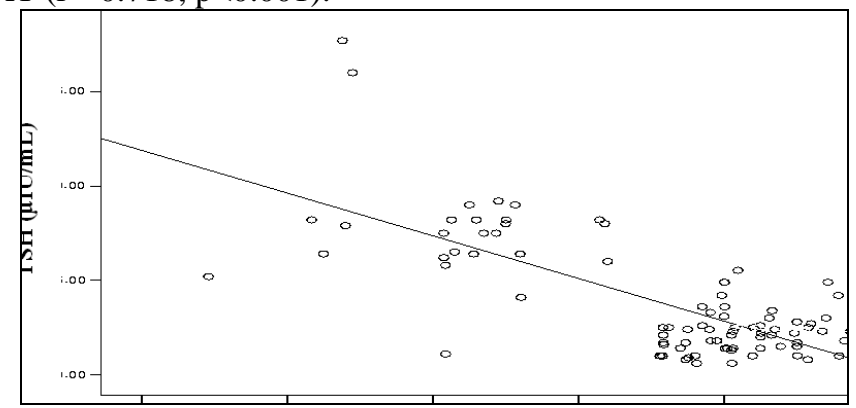

Figure 3: Correlation between thyroid stimulating hormone (TSH) and catalase $(\mathrm{CAT})$ in mentally retarded patients $(\mathrm{r}=-0.718, \mathrm{p}<0.001)$. 
Figure 4: Shows that there is a highly significant negative correlation between TSH and MDA ( $r=-0.420, \mathrm{p}<0.001)$.

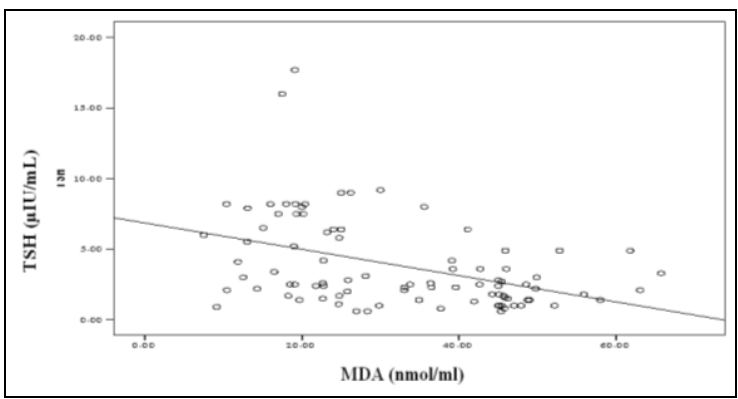

Figure 4: Correlation between thyroid stimulating hormone (TSH) and malondialdehyde (MDA) in mentally retarded patients $(r=-0.420, p<0.001)$.

As shown in figure 5 there is highly significant positive correlation between $\mathrm{FT}_{4}$ and $\mathrm{SOD}(\mathrm{r}=0.696, \mathrm{p}<0.001)$.

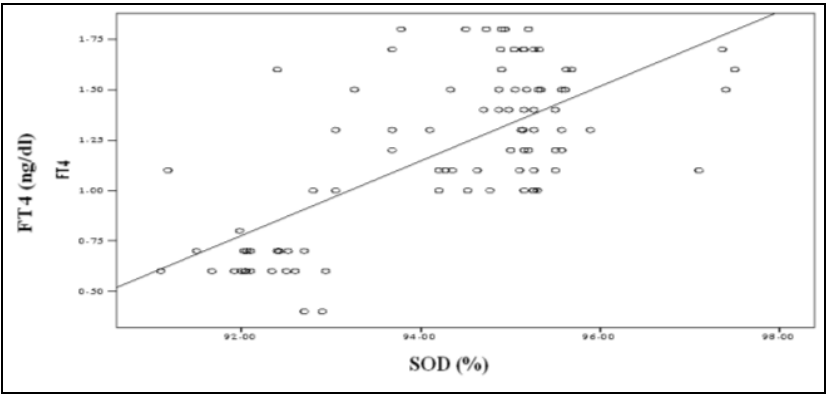

Figure 5: Correlation between free thyroxine (FT4) and superoxide dismutase (SOD) in mentally retarded patients $(\mathrm{r}=0.696, \mathrm{p}<0.001)$.

Figure (6) shows that there is highly significant positive correlation FT4 and CAT $(r=0.659, \mathrm{p}<0.001)$.

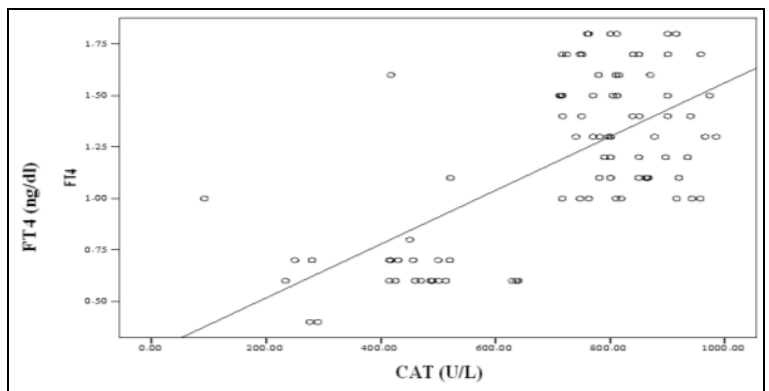

Figure 6: Correlation between free thyroxine (FT4) and catalase (CAT) in mentally retarded patients $(\mathrm{r}=0.659, \mathrm{p}<0.001)$. 
Figure 7 demonstrates that there is highly significant positive correlation $\mathrm{FT}_{4}$ and MDA $(r=0.445, \mathrm{p}<0.001)$.

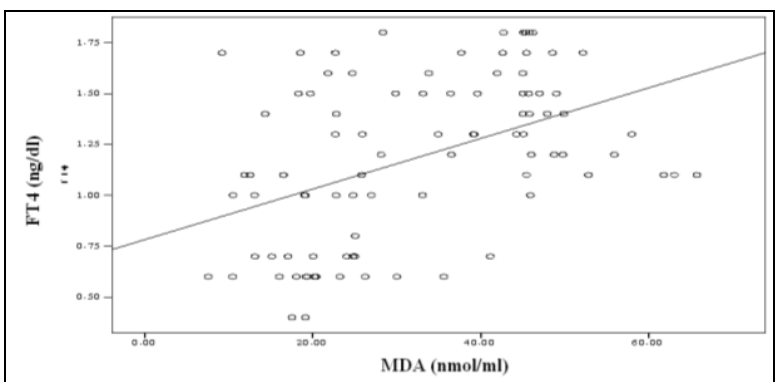

Figure 7: Correlation between free thyroxine $\left(\mathrm{FT}_{4}\right)$ and malondialdehyde (MDA) in mentally retarded patients $(\mathrm{r}=0.445, \mathrm{p}<0.001)$.

As shown in figure 8 there is highly significant positive correlation between SOD and CAT $(r=0.739, \mathrm{p}<0.001)$.

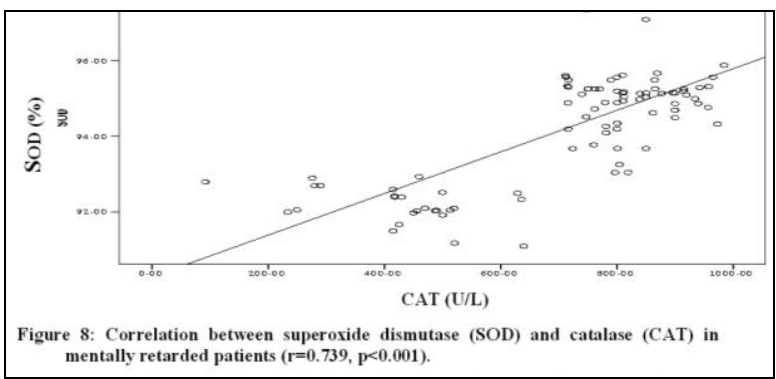

Figure 8: Correlation between superoxide dismutase (SOD) and catalase (CAT) in mentally retarded patients $(\mathrm{r}=0.739, \mathrm{p}<0.001)$.

Figure 9 shows that there is highly significant positive correlation SOD and MDA $(r=0.454, p<0.001)$.

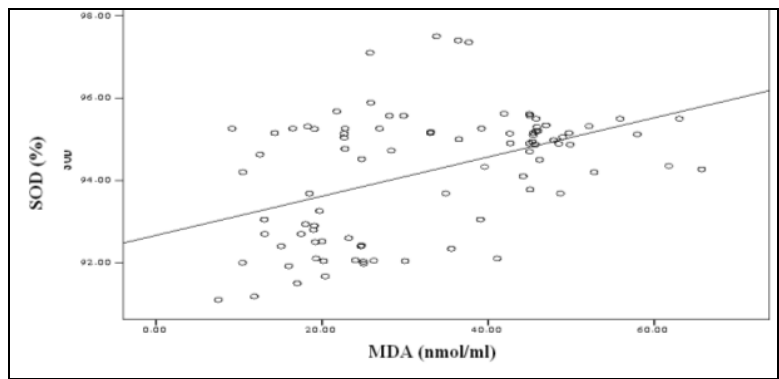

Figure 9: Correlation between superoxide dismutase (SOD) and malondialdehyde (MDA) in mentally retarded patients $(r=0.454, \mathrm{p}<0.001)$. 
As shown in figure 10 there was highly significant positive correlation between CAT and MDA $(r=0.498, p<0.001)$.

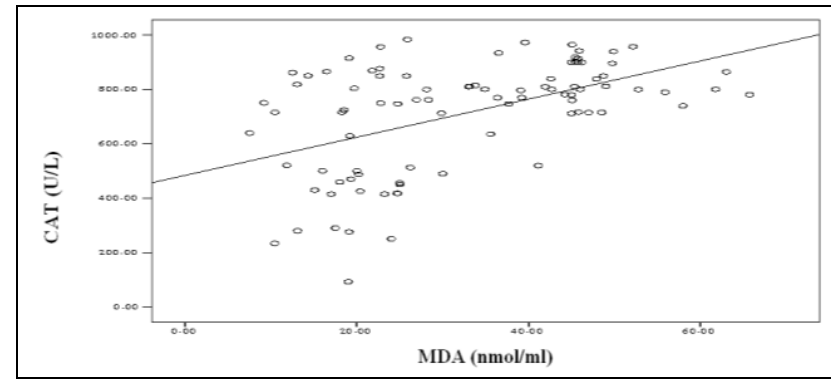

Figure 10: Correlation between catalase (CAT) and malondialdehyde (MDA) in mentally retarded patients $(\mathrm{r}=0.454, \mathrm{p}<0.001)$.

\section{DISCUSSION}

Our study shows that 50 of the studied 60 cases of mentally retarded patients were Down syndrome and the other10 mentally retarded patients consisted of 2 cases had different transition, 2 cases were Edward's syndrome (trisomy 18), one case was Patau syndrome (trisomy 13), three cases had different abnormalities, one case had ring chromosome $46, X Y, r(9)$ and one case was Klinefelter and Down syndrome $(48 X X Y,+21))$. Park et al. ${ }^{(20)}$ studied 20,126 neonatal and found 87 of them with chromosome abnormalities. Of these 87 cases, 53 cases had significant chromosome aneuploidies, including trisomy 13 , trisomy $21,47, \mathrm{XXY}$ or $45, X$, and the other 34 cases presented partial chromosomal deletions or duplications.

Our study reveals that $45 \%$ of the Egyptian mentally retarded patients were hypothyroid and $55 \%$ were euthyroid E. This finding agrees with the finding of Thiel and Steven ${ }^{(21)}$ who reported that individuals with Down syndrome not only have increased risk of hypothyroidism but they also tend to develop a relatively novel mild form of neonatal hypothyroidism.

The present study exhibits that the euthyroid group had highly significantly higher MDA concentration compared to that of the control group. Malondialdehyde is an end product of membrane fatty acid peroxidation (23) and this strongly indicates increase in lipid peroxidation which reflects the state of oxidative stress in mentally retarded patients. In addition, Meguid et al. (22) showed that the level of thiobarbituric acid reactive species,(markers for oxidative stress) was significantly higher in Down syndrome mothers against control.

Moreover, the euthyroid group had high CAT activity compared with those of the control group, supporting the report of Garcez et al. ${ }^{(24)}$ who showed that levels of thiobarbituric acid reactive substances (TBARS), uric acid and serum SOD and CAT activities were higher in the Down syndrome group compared to the control group. Furthermore, catalase 
enzyme is involved in the formation of $\mathrm{O}_{2}, \mathrm{H}_{2} \mathrm{O}$ from $\mathrm{H}_{2} \mathrm{O}_{2}, \mathrm{H}_{2} \mathrm{O}_{2}$ is not considered to be a free radical and it can easily form superoxide and hydroxyl radicals. Removal of $\mathrm{H}_{2} \mathrm{O}_{2}$ by catalase is one of the most important antioxidant defense systems and alterations in catalase activity in tissues indirectly indicate a possible oxidative stress situation ${ }^{(25)}$.

In the euthyroid group there was no significant $(\mathrm{P}>0.05)$ difference of SOD activity compared with the control group. Such finding is in agreement with the finding of Joanna et $\boldsymbol{a l} .{ }^{(\mathbf{2 6})}$. On the other hand, the present study shows that hypothyroid group had low SOD, CAT activities and MDA levels compared with the control group. These results are consistent with the report of Carmeli et al. ${ }^{(27)}$.

The present study showed that euthyroid group had high levels of serum catalase and MDA values, but hypothyroid group had low levels of serum SOD, CAT enzymes and MDA concentration. Oxidative Decreased activity of antioxidant enzymes may be another cause of oxidative stress in this group of patients.

Hypothyroidism-associated oxidative stress was the consequence of both increased production of free radicals and reduced capacity of the antioxidative defense ${ }^{(\mathbf{2 8})}$. Thyroid hypofunction in patients with Down's syndrome in some way was found to be linked with the low serum levels of selenium found in these patients. It was suggested that seleniumcontaining proteins were involved in thyroid hormonal synthesis, by protecting biosynthetic processes against the toxicity of free oxygen radicals ${ }^{(12)}$.

The present study reveals that both the euthyroid and hypothyroid groups had significantly high levels of IL-6 which may reflect chronic inflammatory system activation resulting from recurrent seizures ${ }^{(29)}$. These finding are in agreement with those of Shimada $\boldsymbol{e t} \boldsymbol{a l}^{(30)}$ who reported that cytokine and chemokine levels were elevated to some extent in Down syndrome neonates compared to normal healthy neonate.

Highlighting the data obtained from the present study indicates that thyroid dysfunction occurs in Egyptian subjects with mental retardation thus we recommend routine thyroid function testing in mentally retarded subjects and hypothyroidism should also be kept in mind in children with mental retardation and monitored accordingly.

Moreover, our results add to the understanding of the mechanisms responsible for the increased oxidative stress observed in individuals with MR and may be useful in supporting future antioxidant therapies able to improve the lives of people with mental retardation.

Finally, we found that IL- 6 was generally elevated in patients with mental retardation indicating that poorly controlled seizures may cause inflammatory system activation with potential neurotoxic effects and thus we suggest that chemical inhibitors against the function of IL-6 may be helpful to reduce inflammatory effect of IL-6 in mentally retarded patients. 


\section{CONCLUSION}

Our data revealed a significant linear correlation between circulating thyroid hormone concentrations (TSH, $\mathrm{FT}_{4}$ ) and antioxidant enzymes (SOD and CAT) in Egyptian mentally retarded individuals with chromosomal abnormalities. Increased oxidative stress and elevated IL-6 as well as hypothyroidism are common in Egyptian mentally retarded individuals with chromosomal abnormalities. These findings may be useful in supporting future antioxidant therapies able to improve the lives of people with mental retardation. We suggest that inhibiting the function of IL-6 may be helpful to reduce inflammatory effect of IL-6 in mentally retarded patients.

Acknowledgements: Our thanks to all those with mental retardation, their families, whose unselfish participation has made this work possible. We would also like to thank all members of Genetics Unit, Children Hospital, Mansoura University for their help.

\section{REFERENCES}

1. Jokela M, Batty GD, Deary IJ, Gale CR, Kivimäki M. (2009): Low childhood iq and early adult mortality: The role of explanatory factors in the 1958 British birth cohort. Pediatrica 124(3):380-8.

2. Minns RA (1997): Pre and perinatal conditions contributing to mental retardation. Curr. Opin Psychiatry 10(5):354-9.

3. Jones $K$. and Smith's ed. (2005): Recognizable Patterns of Human Malformation, $6^{\text {th }}$ ed.
Philadelphia, PA: WB Saunders, 404-6.

4. DeVito M, Biegel L, Brouwer A, Brown S, Brucker-Davis F, Cheek AO,Christensen R, Colborn T, Cooke P, Crissman J, Crofton K, Doerge D, Gray E, Hauser P, Hurley P, Kohn M, Lazar J, McMaster S, McClain M, McConnell E, Meier C, Miller R, Tietge J, Tyl R (1999): Screening methods for thyroid hormone disruptors. Environ. Health Perspect., 107(5):407-15.

5. Davis J.D. and Tremont G. (2007): Neuropsychiatric aspects of hypothyroidism and treatment reversibility. Minerva Endocrinol., 32(1):49-65.6

6. Visser WE. , Rijke YB., van Toor H. and Visser TJ. (2011) Thyroid status in a large cohort of patients with mental retardation: the TOP-R (Thyroid Origin of Psychomotor Retardation) study. Clin Endocrinol., (Oxf) 75(3):395-401.

7. Barton BE (1996): The biological effects of interleukin 6 . Med Res Rev., 19(1):87-109.

8. Corsi MM., Dogliotti G., Pedroni F., Palazzi E., Magni P., Chiappelli M. and Licastro F. (2006): Plasma nerve growth factor (NGF) and inflammatory cytokines (IL-6 and MCP-1) in young and adult subjects with Down syndrome: an interesting pathway. Neuro Endocrinol. Lett., 27(5):773-8.

9. Brunssen SH, Moy SS, Toews AD, McPherson CA, Harry GJ (2013): Interleukin-6 (IL-6) receptor/IL-6 fusion protein 
(Hyper IL-6) effects on the neonatal mouse brain: Possible role for IL-6 trans-signaling in brain development and functional neurobehavioral outcomes. Brain Behav Immun., 27(1):42-53.

10. Droge W. (2002): Free radicals in the physiological control of cell function. Physiol. Rev., 82(1):47-95.

11. Smith JA, Park S, Krause JS and Banik NL (2013): Oxidative stress, DNA damage, and the telomeric complex as therapeutic targets in acute neurodegeneration. Neurochem. Int., 62(5):764-75.

12. Kanavin OJ, Aaseth J, Birketvedt GS. (2000): Thyroid hypofunction in Down's syndrome. Is it related to oxidative stress?. Biol. Trace Elem. Res., 78(1-3):35-42.

13. Rooney DE, Czepulkowski BH (1997): Human Chromosome Preparation, Essential Techniques Series, D. Rickwood, Department of Biological and Chemical Sciences, University of Essex, Wivenhoe Park, Colchester, UK. USA: University Press. p.37-8.

14. 14-Sun $Y$, Oberlay $L W$, and $L i$ Y (1988): A simple method for chemical assay of superoxide dismutase. Clin. Chem., 34(3): $497-500$.

15. Aebi H. (1984): Catalase in vitro. Methods Enzymol., 105:121 - 6 .

16. Ohkawa H., Ohishi N. and Yagi K. (1979): Assay for lipid peroxides in animal tissues by thiobarbituric acid reaction. Anal. Biochem., 95(2):351-8.

17. Kiecolt-Glaser JK, Preacher KJ, MacCullum RC, Atkinson
C, Malarkey WB, Glaser $\mathrm{R}$ (2003): Chronic stress and agerelated increases in the proinflammatory cytokine IL-6. Proc. Nat. Acad. Sci., 100(15):9090-5.

18. 18.Hansen HJ, Lafontaine G, Newman ES, Schwartz MK, Malkin A, Mojzisik K, Martin EW, Goldenberg DM (1989): Solving the problem of antibody interference in commercial "sandwich"-type immunoassays of carcinoembryonic antigen. Clin Chem., 35(1):146-51.

19. Norden AG, Jackson RA, Norden LE, Griffin AJ, Barnes MA, Little JA. (1997): Misleading results from immunoassays of serum free thyroxine in the presence of rheumatoid factor. Clin. Chem., 43(6 pt 1):957-62.

20. Park SJ, Jung EH, Ryu RS, Kang HW, Chung HD, Kang HY. (2013): The clinical application of array $\mathrm{CGH}$ for the detection of chromosomal defects in 20,126 unselected newborns. Mol. Cytogenet., 6(1):21.

21. Thiel R. and Steven W. (2007): Down syndrome and thyroid dysfunction. should nutritional support be the first-line treatment?. Med. Hypotheses 69(4):809-15.

22. Meguid NA, Dardir AA, ElSayed EM, Ahmed HH, Hashish AF, Ezzat A. (2010): Homocysteine and oxidative stress in Egyptian children with Down syndrome. Clin. Biochem., 43(12):963-7.

23. Halliwell B, Gutteridge JMC (1996): The biological effects of 
interleukin 6. Med Res Rev., 1:87-109.

24. Garcez ME, Peres W, Salvador M. (2005): Oxidative Stress and hematologic and biochemical parameters in individuals with Down syndrome .Mayo Clin. Proc., 80(12):1607-1611.

25. Beers RF. and Sizer IW (1952): A spectrophotometric method for measuring the breakdown of hydrogen peroxide by catalase. J. Biol. Chem., 195(1):133-40.

26. Śmigielska-Kuzia J, Sobaniec W, Kulak W, Zawada B, Paszko G, Boćkowski L(2007): Antioxidant enzymes and lipid peroxides in children with Down syndrome. Paediatr. Neurol, 5(2):117-120.

27. Carmeli E, Bachar A, Barchad S, Morad M, Merrick J(2008): Antioxidant status in the serum of persons with intellectual disability and hypothyroidism.
Res. Dev. Disabil., 29(5): 431438.

28. Sarandol E., Tas S., Dirican M., and Serdar Z. (2005): Oxidative stress and serum paraoxonase activity in experimental hypothyroidism: Effect of vitamin E supplementation. Cell. Biochem. Funct., 23(1):1-8.

29. Lehtimäki KA, Liimatainen $S$, Peltola J, Arvio M.. (2011): The serum level of interleukin-6 in patients with intellectual disability and refractory epilepsy. Epilepsy Res, 95(1-2): 184-7.

30. Shimada A, Hayashi Y, Ogasawara M, Park MJ, Katoh M, Minakami $\mathrm{H}$, Kitoh $\mathrm{T}$, Kojima S, Kawa K, Kimura $H$. (2007): Pro-inflammatory cytokinemia is frequently found in Down syndrome patients with hematological disorders. Leuk. Res., 31(9):1199-203. 


\section{دور إنترلوكين-7 و الإجهاد التأكسدي في مرضى التخلف العقلي}

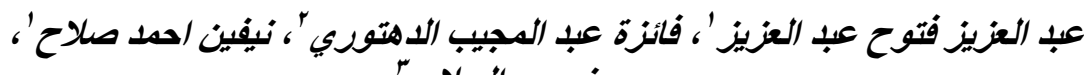

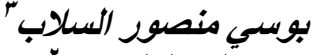

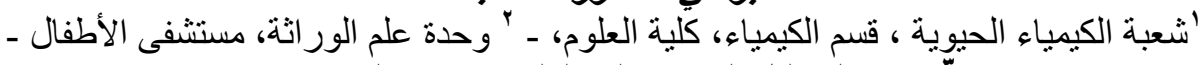

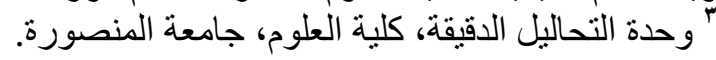

مقدمة : الاضطر ابات الكروموسومية هي السبب الأكثر شيوعا لحدوث التخلف العقلي من

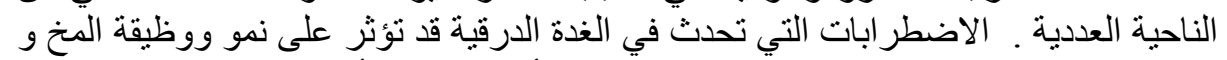

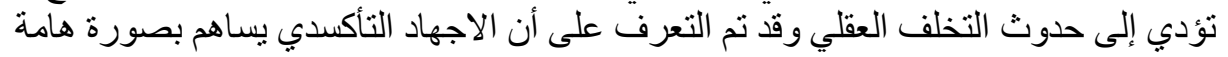

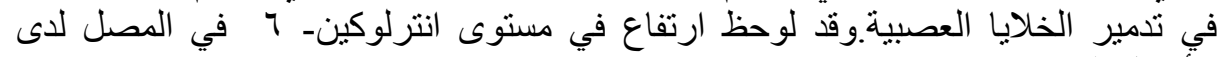

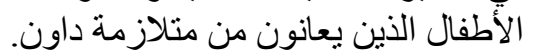

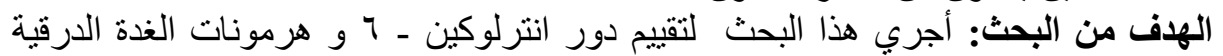

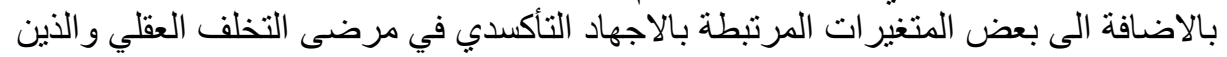

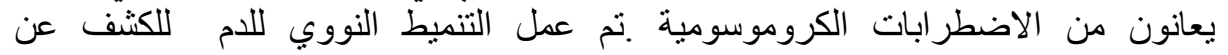

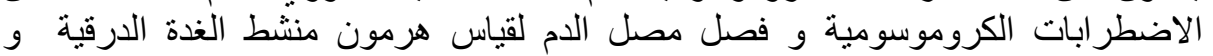

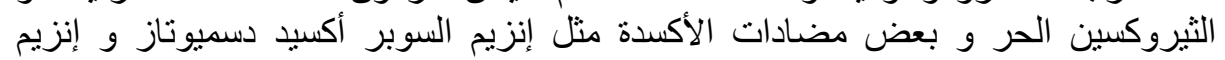

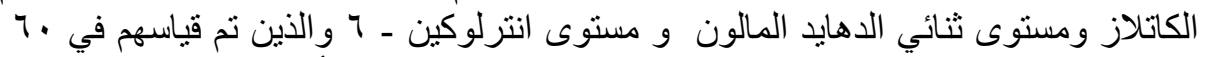

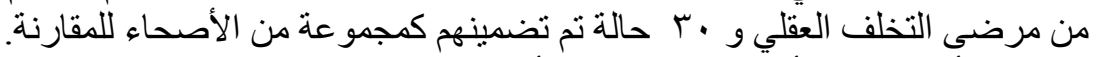

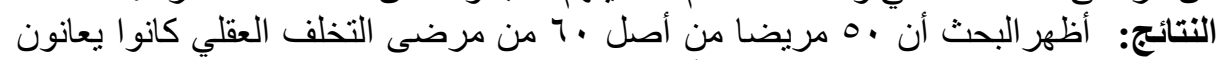

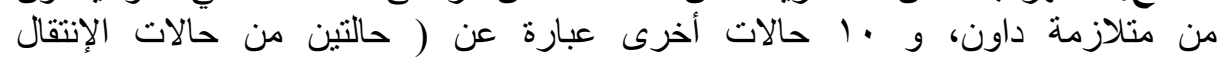

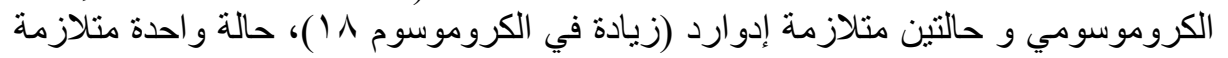

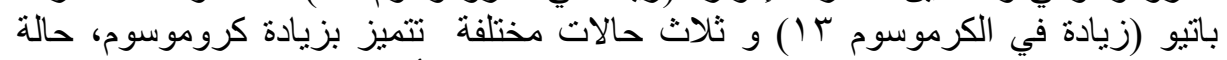

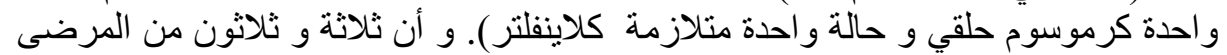

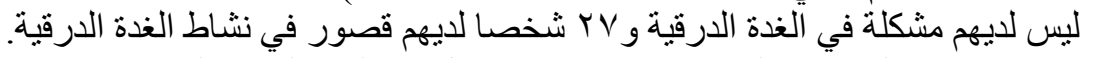

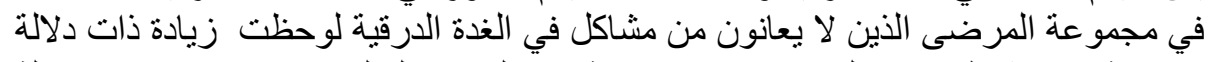

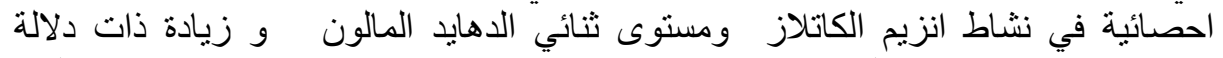

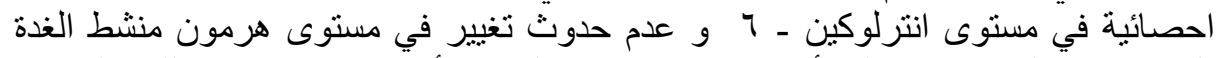

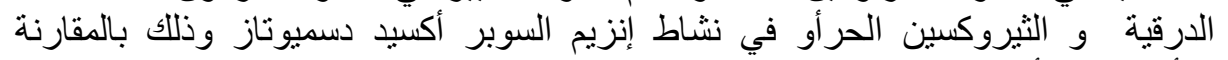

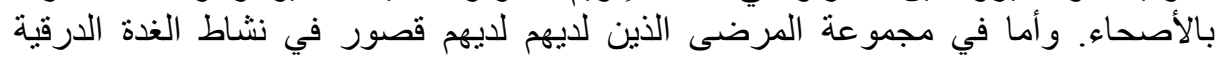

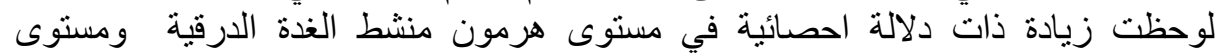

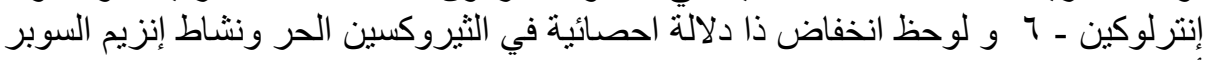

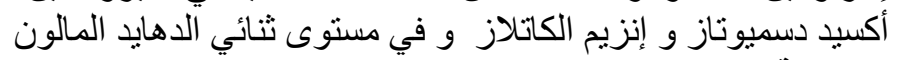

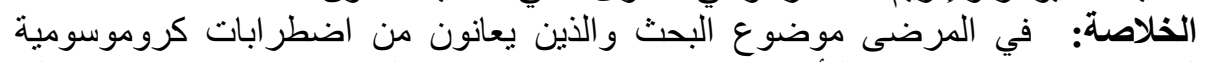

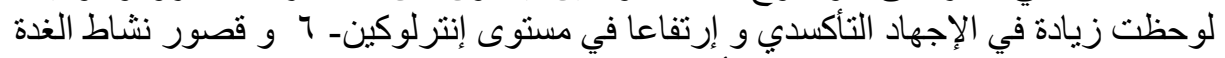

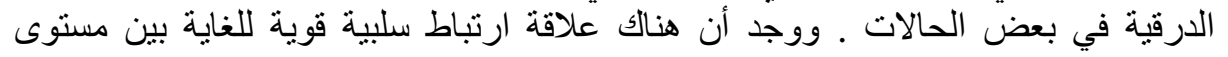


هرمون منشط الغدة الدرقية ونشاط كلا من إنزيم السوبر أكسيد دسميوتاز و إنزيم الكاتلاز

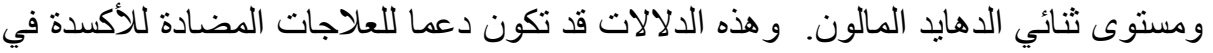

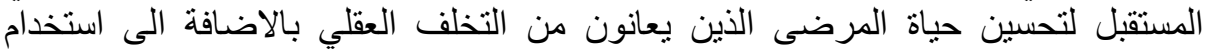

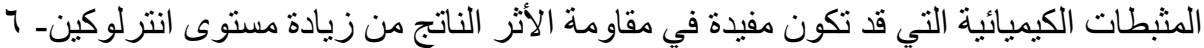

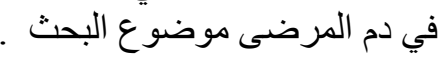

